\title{
Serum Erythropoietin Levels and Inhibitors of Erythropoiesis in Patients with Chronic Renal Failure
}

\author{
Yukitaka Fukushima, Mitsuyuki Fukuda, Kosaku \\ Yoshida, Akihiko Yamaguchi, Yasushi Nakamoto, \\ Akira B. Miura, Tadashi Harada* and Seigi Tsuchida* \\ The Third Department of Internal Medicine and \\ *Department of Urology, Akita University School of \\ Medicine, Akita 010
}

\begin{abstract}
Fukushima, Y., Fukuda, M., Yoshida, K., Yamaguchi, A., Nakamoto, Y., Miura, A.B., Harada, T. and Tsuchida, S. Serum Erythropoietin Levels and Inhibitors of Erythropoiesis in Patients with Chronic Renal Failure. Tohoku J. exp. Med., $150(1), 1-15$ - The role of various factors in erythropoiesis was studied in 13 predialysis patients and 41 hemodialysis patients. Serum erythropoietin (ESF) was measured by the fetal mouse liver cell bioassay in vitro. The effect of uremic sera on heme synthesis and erythroid progenitor cell (CFU-E) formation was examined using normal human bone marrow cultures. Serum ESF levels in both predialysis $(99.9 \pm 45.0 \mathrm{mU} / \mathrm{ml})$ and dialysis $(141.2 \pm 109.7 \mathrm{mU} / \mathrm{ml})$ patients were significantly higher than those in normal controls $(42.0 \pm 25.8 \mathrm{mU} /$ $\mathrm{ml}$ ), although the titers were not sufficiently increased to correct the anemia. Serum ESF concentrations did not correlate with hemoglobin level or inhibition of both heme synthesis and CFU-E formation. Bone marrow CFU-Es in uremic patients were normal in the number, the responsiveness to ESF and the percentage in S-phase. Significant decrease in heme synthesis was observed in dialysis patients. The degree of inhibition of CFU-E formation showed a relationship to hemoglobin levels in uremic patients. By the CFU-E formation assay, the difference in inhibitory effects of the sera obtained from dialysis patients immediately before and after a hemodialysis was significant only under a low ESF concentration $(0.125 \mathrm{U} / \mathrm{ml})$ but not under a high concentration $(1.0 \mathrm{U} / \mathrm{ml})$. In conclusion, inhibition of heme synthesis and CFU-E formation, in addition to inadequate ESF production, plays an important role in renal anemia.

chronic renal failure; fetal mouse liver cell (FMLC) assay ; erythroid progenitor cell (CFU-E); heme synthesis ; erythropoietin (ESF)
\end{abstract}

As chronic renal failure ( $\mathrm{CRF}$ ) progresses, anemia becomes more severe and is hardly improved by hemodialysis. The major cause of renal anemia has been regarded as inadequate erythropoietin (ESF) production to sustain erythropoiesis (Fisher 1980). However, serum ESF levels of uremic patients have been reported to be elevated, normal or decreased. The in vitro bioassay for ESF using fetal mouse liver cells (FMLC) in the present study has advantages in sensitivity,

Received May 8, 1986 ; accepted for publication June 28, 1986. 
convenience and reproducibility (Dunn et al. 1975; Dunn and Napier 1978; de Klerk et al. 1978; Fukushima 1981).

The bone marrow of uremic patients is hypoproliferative. This state is regarded to be due to inhibitory effects of uremic sera on heme synthesis and erythroid progenitor cell (CFU-E) but not to their own marrow function. In addition to inadequate ESF production, inhibitors of erythropoiesis have been postulated to be responsible for the development of progressive anemia in uremic patients (Ohno et al. 1978; Wallner et al. 1978; Radtke et al. 1981). The inhibitors which have been implicated include the polyamines such as spermine and spermidine (Radtke et al. 1981) and parathromone (Meytes et al. 1981); on the contrary, Caro and Erslev (1985) reported that the polyamine spermine is not specific for erythropoiesis and McGonigle et al. demonstrated that parathyoid hormone levels failed to correlate with anemia or inhibition of erythropoiesis in uremic patients (1984c). Target tissues such as animal bone marrow and fetal mouse liver have been used to detect inhibition of erythropoiesis by uremic serum, although these might not reflect all of the in vivo responses of uremic serum on erythropoiesis in the marrow. Therefore, we have used normal human bone marrow cells as target cells for physiologic relevance.

In the present study we examined the effect of possible factors on erythropoiesis in patients with $\mathrm{CRF}$. First, serum ESF levels were measured in uremic patients by the FMLC bioassay and compared with those in normal subjects. Second, we studied quantitative and qualitative abnormalities in the marrow CFU-E formation in uremic patients. Third, serum inhibitors were measured by the fluid marrow culture technique and the CFU-E formation technique.

\section{Materials and Methods}

\section{Patients and controls}

Fifty four patients with CRF were included in the present study. Forty one patients were treated with regular hemodialysis. They consisted of 30 males and 11 females and their ages ranged from 20 to 73 years (mean \pm s.D., $46.3 \pm 15.2$ ). Dialysis periods ranged from 0 to 92 months $(32.1 \pm 27.4)$. They all were anemic and hemoglobin levels were $7.9 \pm$ $1.2 \mathrm{~g} / 100 \mathrm{ml}$ (mean \pm s.D. $)$. Most of them had a history of blood transfusions, but no patient was treated with androgens within three months before collecting blood. Underlying renal disorders of dialysis patients included chronic glomerulonephritis (CGN) $(n=7)$, renal tuberculosis (6), diabetic nephropathy (1), chronic pyelonephritis (1), hydronephrosis with CGN (1), lupus nephritis (1), polycystic kidney (1), myeloma kidney (1) and unknown (23). Predialysis patients consisted of 13 patients. They were classified into three groups according to their serum creatinine levels ; mild $(n=4)$, serum creatinine concentration ranging from 1.5 to $2.4 \mathrm{mg} / 100 \mathrm{ml}$, moderate $(n=7)$, from 2.5 to $7.9 \mathrm{mg} / 100 \mathrm{ml}$, and severe $(n=2)$, over $8.0 \mathrm{mg} / 100 \mathrm{ml}$. None of predialysis patients had a history of blood transfusion within 3 months before collecting blood. Underlying kidney diseases of this group were diabetic nephropathy (3), CGN (1), myeloma kidney (1) and unknown (8). Normal controls consisted of 26 healthy subjects at 20 to 30 years of age (17 males and 9 females). Blood from dialysis patients was collected immediately before regular hemodialysis. All test sera were heat-inactivated at $56^{\circ} \mathrm{C}$ for $30 \mathrm{~min}$ and stored at $-20^{\circ} \mathrm{C}$. 


\section{Fetal mouse liver cell bioassay for ESF}

Serum ESF titers were measured by FMLC bioassay in vitro according to a modification of the technique of Dunn et al. (1975). The assay method was as follows (Fukushima 1981) : Fetal liver cells obtained from dd-Y mouse embryos after 14 days of gestation were suspended in Eagle's Minimum Essential Medium (MEM, GIBCO) containing $5 \%$ fetal calf serum (FCS, Flow). In a concentration of $1.0 \times 10^{6}$ cells $/ \mathrm{ml}$, the culture tubes with $1 \mathrm{ml}$ cell suspension were preincubated for $21-24 \mathrm{hr}$ at $37^{\circ} \mathrm{C}$ in humidified air with $5 \% \mathrm{CO}_{2}$. Subsequently $0.5 \mu \mathrm{Ci}{ }^{59} \mathrm{Fe}$-ferric citrate (Radiochemical Centre, Amersham), which was bound to human transferrin (SIGMA) at $33 \%$ saturation in advance, was added. Following further incubation for $4 \mathrm{hr}$, heme was extracted according to the method of Teale (1959) and the radioactivity in aliquots of the solvent layer was determined in autowell gamma counter. The cultures were set up in triplicate at least. Serum ESF levels were calculated by the formula of de Klerk et al. (1978) to cancel the influence of non-radioactive iron in test sera. Sheep plasma ESF (Connaught, Step III) was used throughout the present study.

\section{Heme synthesis by fluid marrow culture technique}

To investigate the effect of uremic sera on heme synthesis, the fluid marrow culture technique by Krantz et al. (1963) was used with a minor modification. The method was as follows; aspirated marrow cells from normal human controls were washed three times with NCTC 109 (GIBCO). $2 \times 10^{6}$ nucleated cells were cultured in $1 \mathrm{ml}$ NCTC 109 media supplemented with $20 \%$ FCS, $0.4 \mathrm{U}$ of ESF and 10\% test sera. Each tube was incubated for $44 \mathrm{hr}$ at $37^{\circ} \mathrm{C}$ in humidified air with $5 \% \mathrm{CO}_{2}$. Subsequently $1 \mu \mathrm{Ci}{ }^{59} \mathrm{Fe}$-ferric citrate was added to each culture tube, which was incubated for $4 \mathrm{hr}$. The radioiron incorporated into heme was measured by autowell scintillation counter. Each sample was tested in duplicate at least. The influence of non-radioiron in the test serum was corrected by the following formula. True ${ }^{59} \mathrm{Fe}$ incorporation into heme $(\mathrm{cpm})={ }^{59} \mathrm{Fe}$ incorporation $(\mathrm{cpm})$ of actual measurement $\times$ Amount of $\mathrm{Fe}$ in FCS, ${ }^{59} \mathrm{Fe}$-ferric citrate and test serum

\section{CFU-E assay}

To investigate the effect of uremic sera on CFU-E formation in vitro, the plasma clot method modified by Terasawa et al. (1979) was employed. Marrow cells aspirated from normal human controls were centrifuged at $1,200 \mathrm{rpm}$ for $5 \mathrm{~min}$. Buffy coat cells were washed three times with Hank's MEM (GIBCO) and cultured in a concentration of $1 \times 10^{5}$ cells per clot. The culture media contained $20 \% \mathrm{FCS}, 20 \% \alpha$-medium (Flow), $10 \% \mathrm{ESF}$ $(0.5 \mathrm{U} / \mathrm{ml}), 10 \%$ beef embryo extract (GIBCO), 10\% deionized bovine serum albumin (SIGMA), $10 \%$ buffy coat cells, $10 \%$ citrated AB type serum and $10 \%$ test serum. $0.4 \mathrm{ml}$ of the mixture was plated in the center of a $35 \mathrm{~mm} \times 10 \mathrm{~mm}$ Petri dish (Falcon Plastics) and $0.6 \mathrm{ml}$ of $\alpha$-medium was placed around the plasma clot. CFU-E formation was expressed as a percentage of the colony formation without added sera. Bone marrow CFU-E of patients with $\mathrm{CRF}$ was assayed according to the same method. $10 \% \alpha$-medium was included in the culture mixture instead of $10 \%$ test serum, and ESF concentration was 1.0 $\mathrm{U} / \mathrm{ml}$. The percentage of $\mathrm{CFU}-\mathrm{E}$ in $\mathrm{S}$-phase was determined by methyl- ${ }^{3} \mathrm{H}$-thymidine suicide assay by Becker et al. (1965). The dish was incubated at $37^{\circ} \mathrm{C}$ in humidified air containing $5 \% \mathrm{CO}_{2}$ for 7 days. After the incubation, the clot was fixed in $5 \%$ glutaraldehyde and stained with benzidine and giemsa solution. Colonies consisting of 8 or more cells which were benzidine positive, were counted as erythroid colonies. Before examining the suppression of CFU-E formation by uremic sera, we determined the normal range of CFU-E formation of normal sera in comparison with CFU-E formation without added sera at first. We examined the effects of 10 normal sera on CFU-E formation of 4 other normal human bone marrow cells. The presence of inhibitors and stimulators could be judged when the colony growth with uremic sera decreased out of 2 s.D. (lower than $70 \%$ ) and increased out of 2 s.D. (more than $127 \%$ ), respectively. Target cells were normal human bone marrow cells of one person only when the effect of uremic sera of dialysis patients on CFU-E 
formation before and after a hemodialysis was examined.

Student's $t$-test, paired $t$-test and linear regression analysis were used for statistical comparisons.

\section{RESULTS}

In patients with impaired renal function the serum creatinine concentration ranged from 1.8 to $25 \mathrm{mg} / 100 \mathrm{ml}$ and the hemoglobin from 2.7 to $12.1 \mathrm{~g} / 100 \mathrm{ml}$. The severity of anemia was found to be related inversely to the degree of impaired renal function $(r=-0.439, p<0.01 ;$ Fig. 1$)$.

\section{Serum ESF levels}

Fig. 2 shows serum ESF levels in normal controls and patients with CRF. Serum ESF levels in normal controls were $42.0 \pm 25.8 \mathrm{mU} / \mathrm{ml}(n=18$, mean \pm S.D. $)$. The mean values in males and females were $37.6 \pm 23.9 \mathrm{mU} / \mathrm{ml}(n=11)$, and $48.9 \pm$ $27.0 \mathrm{mU} / \mathrm{ml}(n=7)$, respectively. There was no significant difference between males and females. Hemoglobin levels, serum creatinine levels and dialysis periods of 28 dialysis patients were $7.8 \pm 1.3 \mathrm{~g} / 100 \mathrm{ml}, 12.2 \pm 3.7 \mathrm{mg} / 100 \mathrm{ml}$ and $35.6 \pm 26.6$ months, respectively. Predialysis patients consisted of 2 mild cases, 3 moderate cases and 2 severe cases. Hemoglobin levels were $8.9 \pm 3.1 \mathrm{~g} / 100 \mathrm{ml}$ and

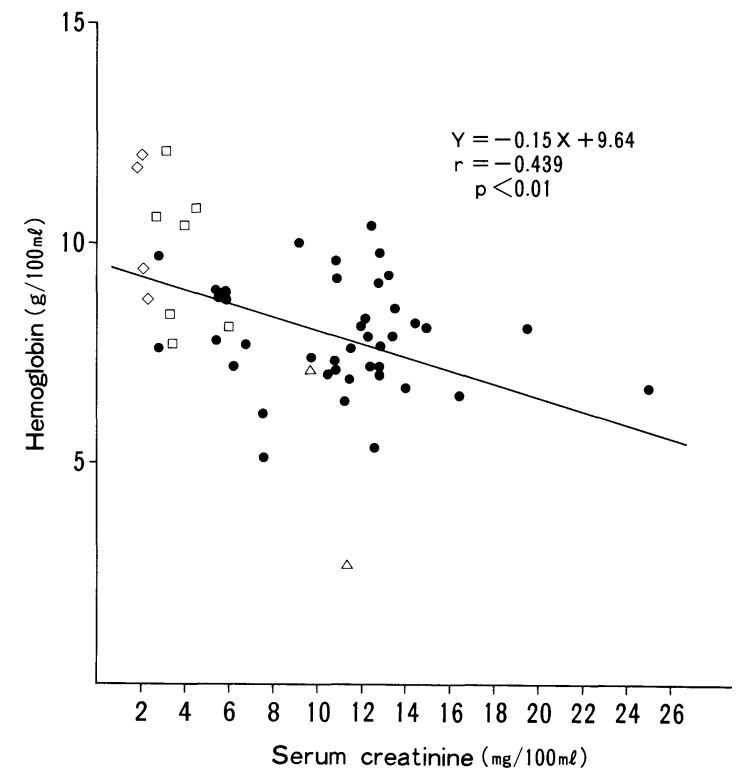

Fig. 1. Relationship between hemoglobin and serum creatinine concentration in 54 patients at various stages of CRF. The open lozenge $(\diamond)$, the open square $(\square)$ and the open triangle $(\triangle)$ represent predialysis patients whose creatinine levels ranged from 1.5 to $2.4 \mathrm{mg} / 100 \mathrm{ml}$, from 2.5 to $7.9 \mathrm{mg} / 100 \mathrm{ml}$, from $8.0-12.0 \mathrm{mg} / 100 \mathrm{ml}$, respectively, and the closed circle $(\bullet)$ represents patients with regular hemodialysis treatment. These marks were used in our figures throughout. 


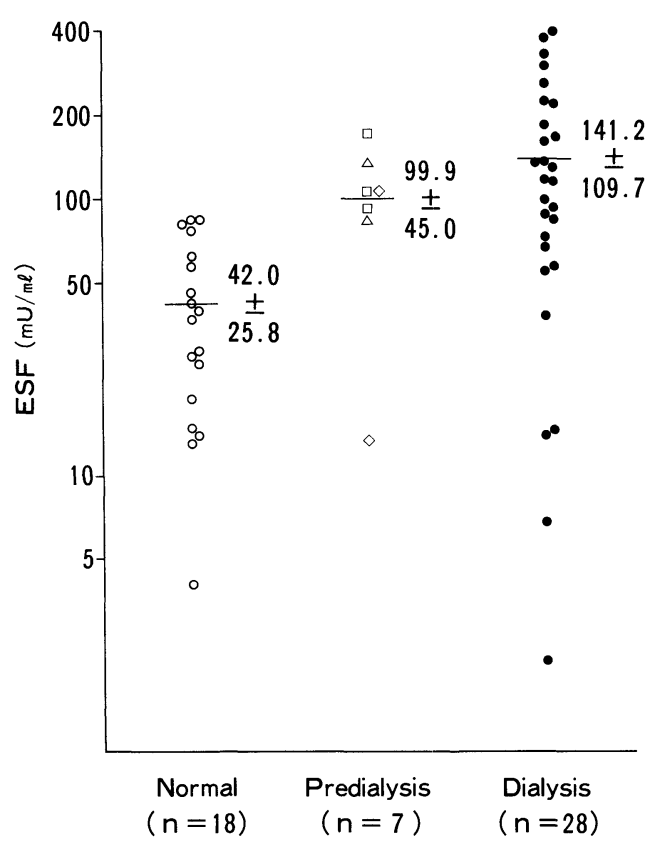

Fig. 2. Serum ESF levels in 18 normal subjects, 7 predialysis patients with varying degrees of renal failure and 28 patients with regular hemodialysis treatment. The open circle $(O)$ represents normal controls. This mark was used in our figures throughout. Numbers are means \pm S.D.

serum creatinine values were $5.3 \pm 3.4 \mathrm{mg} / 100 \mathrm{ml}$. Serum ESF levels in 28 dialysis patients were $141.2 \pm 109.7 \mathrm{mU} / \mathrm{ml}$ which were significantly higher than normal values $(p<0.01)$. Serum ESF levels in 7 predialysis patients were $99.9 \pm$ $45.0 \mathrm{mU} / \mathrm{ml}$ and were also significantly higher than normal values $(p<0.05)$. Serum ESF levels of uremic patients (predialysis and dialysis patients) were not correlated with hemoglobin levels $(n=35)$ or serum creatinine levels $(n=35)$.

Quantitative and qualitative abnormalities in marrow $C F U-E$ formation

Fig. 3 shows the numbers of bone marrow CFU-Es of normal subjects and uremic patients. The mean value of 9 dialysis patients was $194 \pm 75 / 1 \times 10^{5}$ cells (mean \pm s.D.) and that of 5 predialysis patients ( 2 mild cases and 3 moderate cases) was $179 \pm 51 / 1 \times 10^{5}$ cells and that of all 14 cases taken together was $189 \pm 68 / 1 \times$ $10^{5}$ cells at $1.0 \mathrm{U} / \mathrm{ml}$ concentration of ESF. In comparison with the mean value of 11 normal subjects which was $236 \pm 81 / 1 \times 10^{5}$ cells, it was lower in CRF, but the difference was not statistically significant.

Fig. 4 shows the ESF dose-response curves for bone marrow CFU-Es in 4 normal subjects and 6 uremic patients. 100\% indicates the number of bone marrow CFU-E at $1.0 \mathrm{U} / \mathrm{ml}$ concentration of ESF. The responsiveness of CFU-E formation to ESF was not reduced in 6 uremic patients ( 2 mild cases, 2 moderate cases, 2 dialysis cases) as compared with that in 4 normal controls. There was no 


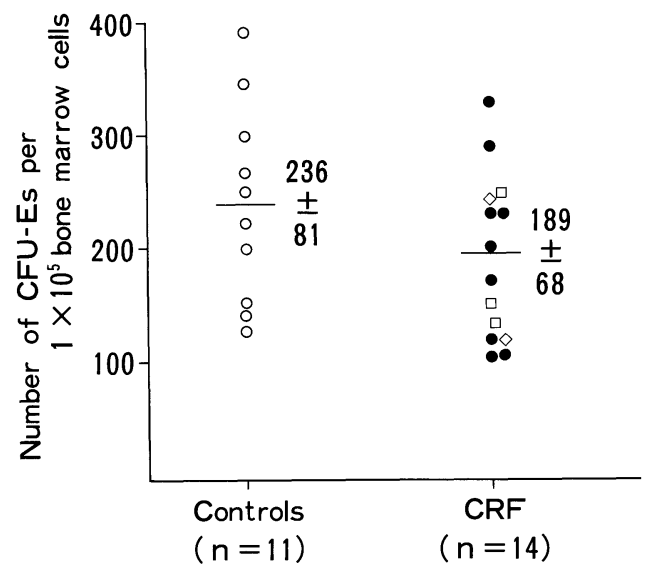

Fig. 3. Numbers of CFU-Es per $1 \times 10^{5}$ bone marrow cells of 11 normal controls, 5 predialysis patients and 9 dialysis patients at $1.0 \mathrm{U} / \mathrm{ml}$ concentration of ESF. Numbers are means \pm S.D.

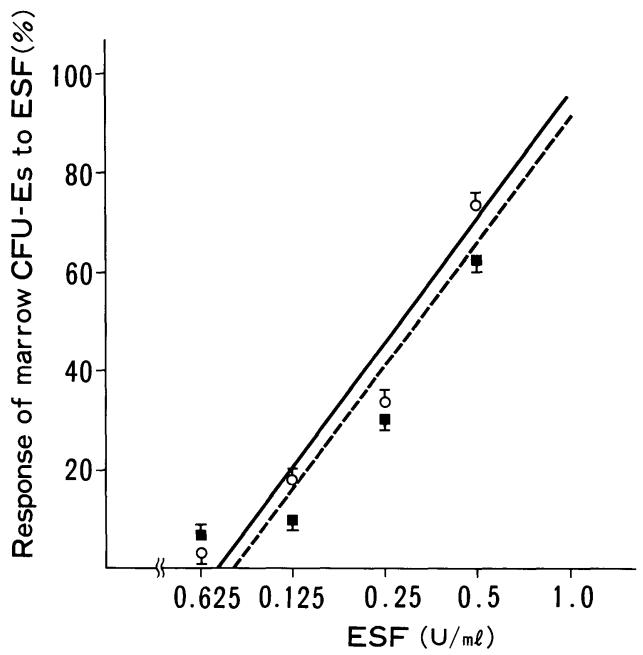

Fig. 4. ESF dose response curves for bone marrow CFU-E formation in normal controls (solid line, $y=36.4 x+96.3, r=0.98, p<0.01$ ) and uremic patients (dotted line, $y=35.8 x+90.7, r=0.95, p<0.01$ ). The open circle $(0)$ only in this figure represents the mean numbers of marrow CFU-Es in 4 normal subjects and the closed square ( $)$ represents the mean numbers of marrow CFU-Es in 6 uremic patients. Vertical bar indicates 1 s.E. of the mean. No significant difference is observed.

CFU-E formation in the absence of ESF.

The percentage of bone marrow CFU-Es in S-phase was $66.8 \pm 2.8 \%$ (mean \pm S.D.) in 8 normal subjects and $62.8 \pm 4.8 \%$ in 7 uremic patients ( 1 mild case, 2 moderate cases and 4 dialysis cases). The difference was not statistically significant (Fig. 5). 


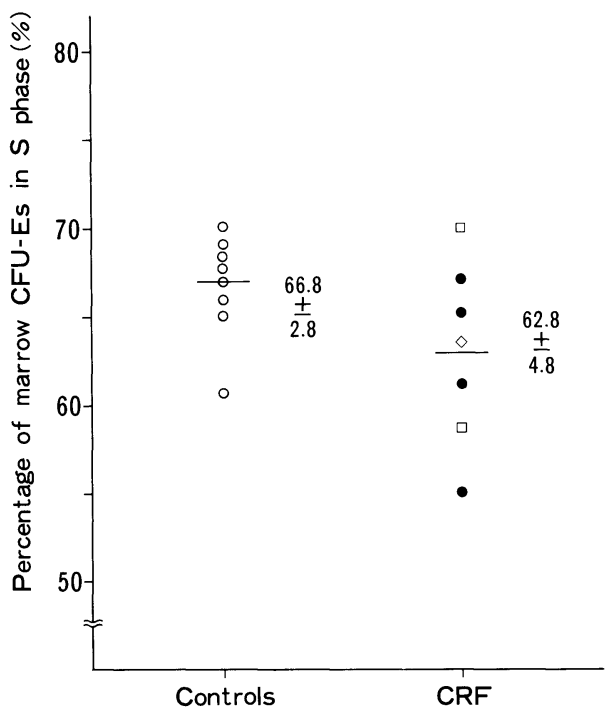

Fig. 5. Percentage of marrow CFU-Es in S-phase in 8 normal subjects, 3 predialysis patients and 4 dialysis patients. Numbers are means \pm s.D.

\section{Serum inhibitors measured by fluid marrow culture technique}

The effects of uremic sera on heme synthesis were investigated by the fluid marrow culture techniques. The response of normal human bone marrow cells to ESF was defined as the ratio of the absolute value of ${ }^{59} \mathrm{Fe}$ incorporation in various ESF concentrations to that of ${ }^{59} \mathrm{Fe}$ incorporation in the absence of ESF. Heme synthesis was maximum at $200 \mathrm{mU} / \mathrm{ml}$ of $\mathrm{ESF}$ and the ratio was $209 \pm 51 \%$ ( $n=$ 11). ${ }^{59} \mathrm{Fe}$ incorporation into heme in 26 normal sera was $607 \pm 430 \mathrm{cpm}$, while it was $508 \pm 304 \mathrm{cpm}$ in 9 uremic sera of predialysis patients $(2$ mild cases and 7 moderate cases) and $395 \pm 280 \mathrm{cpm}$ in 41 uremic sera of dialysis patients. Absolute values of ${ }^{59} \mathrm{Fe}$ incorporation in uremic sera of dialysis patients were significantly lower than those of normal sera $(p<0.05)$. Although this decrease in heme synthesis of predialysis patients did not reach significant levels, it did parallel the progressive anemia in predialysis patients with deteriorating renal function (Table 1). The degree of inhibition of heme synthesis did not correlate with either hemoglobin levels or serum ESF concentrations.

\section{Serum inhibitors measured by $C F U-E$ formation technique}

The effects of 10 normal sera on CFU-E formation of 4 normal human bone marrow cells were shown in Table 2. The mean percentage of CFU-E formation containing 10 normal sera to CFU-E formation without test sera ranged from $76.0 \pm 11.5$ (mean \pm s.D.) to $118.8 \pm 19.4 \%$, with a mean of $98.2 \pm 14.2 \%$, and coefficients of variation ranged from 9.9 to $21.7 \%$, with a mean of $14.8 \pm 3.2 \%$. In respect of 4 target cells, the CFU-E formation containing 10 normal sera ranged 
TABLE 1. Effects of serum of each group on heme synthesis $\left({ }^{59} \mathrm{Fe}\right.$ incorporation) of normal human bone marrow cells $\left(\mathrm{cpm} / 2 \times 10^{6}\right.$ nucleated cells)

\begin{tabular}{|c|c|c|c|}
\hline Clinical data & $\begin{array}{l}\text { Normal } \\
\text { subjects }\end{array}$ & $\begin{array}{l}\text { Predialysis } \\
\text { patients }\end{array}$ & $\begin{array}{l}\text { Dialysis } \\
\text { patients }\end{array}$ \\
\hline No. studied & 26 & 9 & 41 \\
\hline Hemoglobin $(\mathrm{g} / 100 \mathrm{ml})$ & - & $\begin{array}{c}9.9 \pm 1.6 \\
(7.7 \sim 12.1)\end{array}$ & $\begin{array}{c}7.9 \pm 1.2 \\
(5.1 \sim 10.4)\end{array}$ \\
\hline Creatinine $(\mathrm{mg} / 100 \mathrm{ml})$ & - & $\begin{array}{c}3.5 \pm 1.1 \\
(2.1 \sim 6.0)\end{array}$ & $\begin{array}{c}11.1 \pm 4.1 \\
(2.8 \sim 25.0)\end{array}$ \\
\hline $\begin{array}{l}\text { Experimental } \\
\text { results }(\mathrm{cpm})\end{array}$ & $\begin{array}{c}607 \pm 430 \\
(123 \sim 2090)\end{array}$ & $\begin{array}{c}508 \pm 304 \\
(73 \sim 1129)\end{array}$ & $\begin{array}{c}395 \pm 280 \\
(41 \sim 1528)\end{array}$ \\
\hline $\begin{array}{l}\text { Experimental } \\
\text { numbers }\end{array}$ & 15 & 5 & 15 \\
\hline $\begin{array}{l}\text { Summation }(\%) \\
p \text { values* }\end{array}$ & 100 & $\begin{array}{c}84 \\
0.538\end{array}$ & $\begin{array}{c}65 \\
0.019\end{array}$ \\
\hline
\end{tabular}

Mean \pm s.D.

The numbers in parentheses show the ranges.

${ }^{*} p$ values vs. normal by ${ }^{59} \mathrm{Fe}$ incorporation into heme (cpm).

from $91.2 \pm 5.2$ to $102.5 \pm 25.7 \%$ (mean \pm s.D., $98.5 \pm 4.3 \%$ ), and coefficients of variation ranged from 5.7 to $25.1 \%$ (mean \pm s.D., $18.3 \pm 7.5 \%$ ). It is possible that several normal human bone marrow cells are used as target cells, although coefficients of variation are sightly large. We determined that CFU-E formation containing normal sera was $98.2 \pm 14.2 \%$ in comparison with CFU-E formation without added sera, and compared the effect of uremic sera on CFU-E formation with that of normal sera.

Fig. 6 shows the relationship between hemoglobin levels and the degree of inhibition of CFU-E formation by uremic sera. The lower the hemoglobin, the greater the degree of inhibition of CFU-E formation. The effects of 49 uremic sera on CFU-E formation ranged from 6 to $153 \%$ with a mean \pm 1s.D. of $84.7 \pm 31.0$ $\%$. The value was $81.9 \pm 40.3 \%$ in predialysis patients and $85.4 \pm 28.0 \%$ in dialysis patients. Serum inhibitors as defined above (see Materials AND Methods) were found in 15 out of 49 uremic sera (4 sera out of 10 predialysis patients and 11 sera out of 39 dialysis patients) and serum stimulators were found in 5 out of 49 uremic sera ( 2 sera out of predialysis patients and 3 sera out of dialysis patients). However, the correlation between the degree of inhibition of CFU-E formation and the serum ESF concentration was not seen $(n=32)$.

Fig. 7 shows the effect of uremic sera of dialysis patients on CFU-E formation immediately before and after a single $5 \mathrm{hr}$ hemodialysis. The number of CFU-Es under 1.0 or $0.125 \mathrm{U} / \mathrm{ml}$ concentration of ESF in 9 normal subjects was $88 \pm 19$ (mean \pm s.D.) and $23 \pm 6$ per dish, which were both $100 \%$ in comparison with CFU-E formation without added sera. The effects of 11 uremic sera on CFU-E formation under $1.0 \mathrm{U} / \mathrm{ml}$ concentration of ESF before a hemodialysis ranged 
Erythropoietin and Inhibitors in Uremia

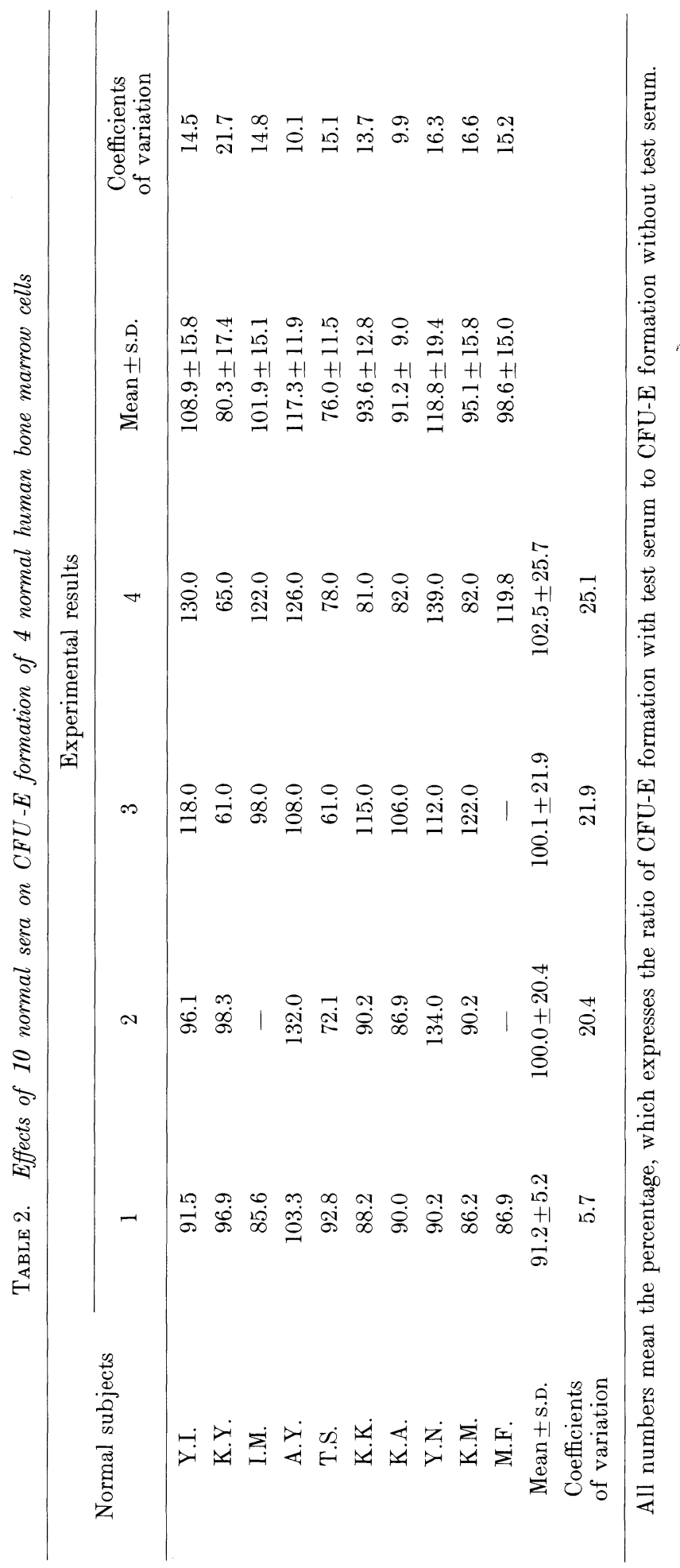




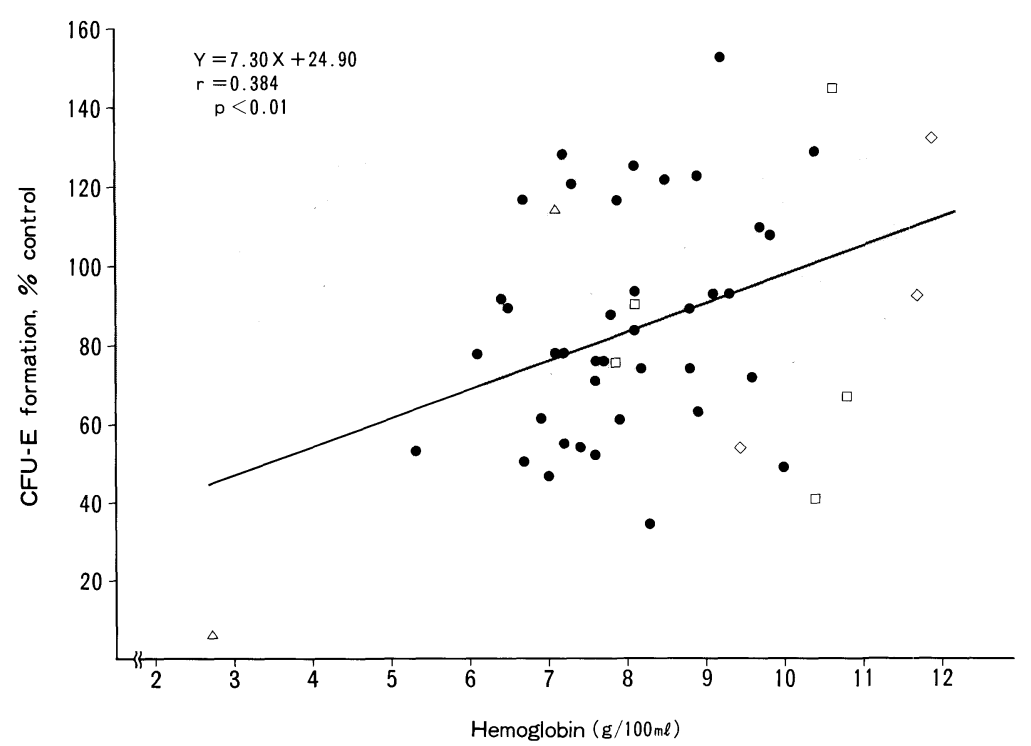

Fig. 6. Relationship between hemoglobin and inhibition of CFU-E formation in 49 patients with $\mathrm{CRF}$. A grayish zone represents the normal range of CFU-E formation containing normal sera (mean \pm 2 s.D.).

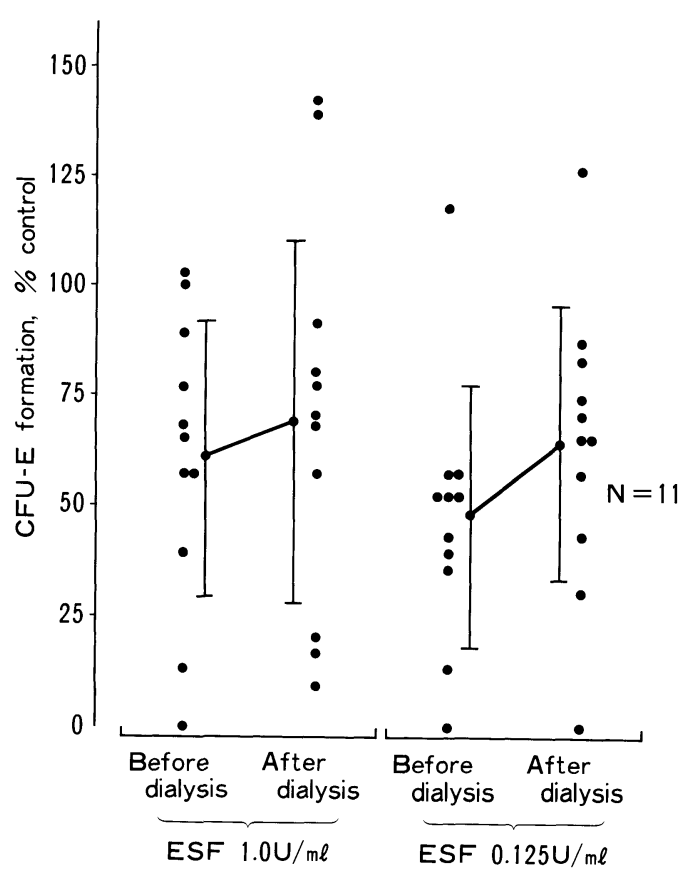

Fig. 7. The change immediately before and after a single $5 \mathrm{hr}$ hemodialysis in the effect of sera from dialysis patients on CFU-E formation. 
from 0 to $103 \%$ (mean \pm s.D., $61 \pm 32 \%$ ), and the values after a hemodialysis ranged 9 to $142 \%(69 \pm 41 \%)$. Under $0.125 \mathrm{U} / \mathrm{ml}$ concentration the values before a hemodialysis ranged from 0 to $122 \%(48 \pm 29 \%)$, and the values after a hemodialysis ranged 0 to $126 \%(64 \pm 31 \%)$. Before a hemodialysis, the inhibitory effect of uremic sera on CFU-E formation was significantly greater under both $1.0 \mathrm{U} / \mathrm{ml}(p<0.05)$ and $0.125 \mathrm{U} / \mathrm{ml}(p<0.01)$ concentrations of ESF than that of normal sera. After the hemodialysis, the inhibition was not statistically significant under either 1.0 or $0.125 \mathrm{U} / \mathrm{ml}$ concentration of ESF. The inhibitory effect of uremic sera on CFU-E formation immediately after a single hemodialysis was significantly weaker than that immediately before the hemodialysis under $0.125 \mathrm{U} / \mathrm{ml}$ concentration of $\operatorname{ESF}(p<0.01)$, but it was not statistically significant under $1.0 \mathrm{U} / \mathrm{ml}$ concentration of ESF.

\section{Discussion}

In recent years, the causes of renal anemia have been extensively studied. Fisher (1980) have raised two major causes; a shortened red cell life span and a decreased erythropoiesis. The shortened red cell life span is absent in patients with blood urea levels below $135 \mathrm{mg} / \mathrm{dl}$ (Shaw 1967). Therefore, it might not play a major role in renal anemia. The decrease of erythropoiesis is divided into the inadequate ESF production and the presence of inhibitors of erythropoiesis.

Serum ESF levels of patients with CRF have been considered to be lowered, because they could not be measured by the standard polycythemic mouse assay. However, new sensitive assays for ESF have been developed and a variety of results have been reported. The fetal mouse liver cell (FMLC) bioassay for ESF has advantages of high sensitivity, specificity and reproducibility (Dunn et al. 1975 ; Dunn and Napier 1978; de Klerk et al. 1978). However, these in vitro bioassays faced the criticism that they might be affected by inhibitors or stimulators of erythropoiesis also present in the serum. In this respect, we used the modified assay method of de Klerk et al. (1978). The problem of nonspecific serum substances influencing the results of measurement of serum ESF levels is circumvented by assaying each test serum against a standard ESF preparation dissolved in the same test serum (Fukushima 1981). This allows valid quantitative estimation of the serum ESF titer provided that the dose-response curve of standard and test serum can be shown to be linear and parallel. Using FMLC assay, Radtke et al. (1979) reported that serum ESF levels in predialysis and dialysis patients were significantly higher than those in normal controls, while de Klerk et al. (1982) found that they were significantly lower. Müller-Wiefel and Schärer (1983) observed that serum ESF levels of predialysis children were almost the same as those of healthy children, whereas those of dialysis children were significantly decreased.

By the previously developed radioimmunoassay, serum ESF levels in patients with CRF were generally higher significantly or not significantly than those in 
normal controls (Sherwood and Goldwasser 1979; Zaroulis et al. 1981; Cotes 1982 ; McGonigle et al. 1984a, b, 1985) In our first study we have demonstrated that serum ESF levels in both predialysis and dialysis patients are significantly higher than those in normal controls. The reason why there is a discrepancy of results between de Klerk et al. (1982) and ours can not be well explained. Widely scattered values of ESF were seen, and we could not find a significant correlation between the degree of anemia and serum ESF levels. These data suggest that renal anemia is also influenced by factors other than ESF deficiency, and the presence of inhibitors of erythropoiesis have been postulated to be of significance (Fisher 1980; de Klerk et al. 1982).

In our second experiment we studied on the presence of quantitative and qualitative differences between CFU-Es in the bone marrow from normal subjects and uremic patients. Bone marrow CFU-Es in uremic patients were normal in the percentage in S-phase, as well as the number and the responsiveness to ESF so that renal anemia was not due to the defect of erythroid progenitor cells in proliferation and differentiation. These observations are consistent with the findings of Wallner et al. (1975) and Fisher et al. (1975).

In order to investigate inhibitors of erythropoiesis in uremic sera, bone marrow cells from dogs, rabbits and mice have been used as the target cells in many previous studies. However, in these methods the possibility that effects of inhibitors were amplified could not be denied. We did use the normal human bone marrow cells as the target cells for being more physiological. However, limited numbers of normal bone marrow cells per one person make it impossible to examine the effects of many uremic sera on CFU-E formation at one experiment. They also increase the amount of scatter. Moreover, there are many problems related to antibodies such as blood type, transfusion, and so forth. The influence of these antibodies on heme synthesis and CFU-E formation must be taken into consideration in carrying out the experiments. It can not be as yet distinguished between inhibitors of erythropoiesis and antibodies to them.

In our third experiment we studied the inhibitory effects of uremic sera on heme synthesis of normal human bone marrow cells (Table 1). We found that decreasing rates of heme synthesis were seen significantly in serum samples taken from dialysis patients but not significantly from predialysis patients. However, the correlation between hemoglobins of these uremic patients and percent control of heme synthesis (heme synthesis of uremic sera/heme synthesis of normal sera) could not be seen. In this point, our data were not in agreement with Wallner and Vautrin (1981). However, as shown in Table 1, our observation, that the levels of inhibitory substance develop as renal disease progresses, was in agreement with them.

In our final experiment we studied the effect of uremic sera on CFU-E formation of normal human bone marrow cells. Bone marrow cells from different normal subjects were used as target cells, since the absolute numbers of aspirated 
marrow cells were limited. The response of normal marrow CFU-E formation to normal sera was good in the presence of ESF. As shown in Table 2, the mean values of 10 normal sera were almost $100 \%$ except experiment $1(91.2 \%)$. We found that the effect on CFU-E formation was variable $(76.0 \%-118.8 \%)$ even in normal sera taken from 10 normal subjects without renal disease or anemia.

We found a relationship between the degree of anemia and the degree of inhibition of CFU-E formation by uremic sera. The more severe the anemia, the greater the degree of inhibition of CFU-E formation by uremic sera in normal human marrow culture. This observation agrees with that of Wallner and Vautrin (1981) and McGonigle et al. (1984a, b, 1985). In our study the uremic serum with the strongest inhibitory effects on CFU-E formation was from a 32 year-old-female patient immediatedly before the onset of hemodialysis, whose hemoglobin level was $2.7 \mathrm{~g} / 100 \mathrm{ml}$ and creatinine level was $11.3 \mathrm{mg} / 100 \mathrm{ml}$. The concentration of the patient's serum added in culture was $10 \%$ and the CFU-E formation was only $6.0 \%$ of that without added sera. When the concentration was decreased to $5 \%$ and $2.5 \%$, it was $36 \%$ and $53 \%$, respectively, indicating that the inhibitory factor of CFU-E growth was dose-dependent. Recently, Delwiche et al. (1986) reported that uremic sera exerted similar dose-dependent inhibitory effect on erythroid, gramulocyte-macrophage, and megakaryocytic colony formation in murine bone marrow culture and that these inhibitors as definced in vitro may be of little importance since neutropenia and thrombocytopenia are observed infrequently among uremic patients. In this respect, we demonstrated that such inhibitors are of physiologic significance in vivo by the effect of uremic sera on CFU-E formation in normal human marrow. In the present study uremic sera we examined were taken mostly from patients receiving regular hemodialysis therapy. Even in dialysis patients inhibitors of erythropoiesis appeared to play an important role in renal anemia.

In comparison with normal sera, the inhibitory effect of uremic sera on the CFU-E formation was greater before a hemodialysis although the inhibition was not significant even after the hemodialysis. This result suggests that such inhibitors are dialized out to some extent by the hemodialysis. The change immediately before and after a single $5 \mathrm{hr}$ hemodialysis in the inhibitory effect of sera from dialysis patients on CFU-E formation showed a significant decrease under 0 . $125 \mathrm{U} / \mathrm{ml}$ concentration of ESF, but not under $1.0 \mathrm{U} / \mathrm{ml}$ concentration of ESF. It appears that the inhibition is strengthened especially under low ESF concentration.

In this study our observation indicates that as renal function deteriorates, anemia develops and the serum ESF concentration increases gradually. It appears that ESF is produced above the normal range by the residual capability of the kidneys. However, the titers were not sufficiently increased to correct the anemia and therefore reflect a relative defeciency of ESF as compared with patients with comparable degrees of anemia and normal renal function. It was 
the degree of serum inhibition of CFU-E formation rather than the serum ESF level which correlated with the degree of anemia. The severity of anemia for the same level of renal function varied widely in uremic patients in our study. Similarly, the degrees of inhibition of CFU-E formation also showed a wide scatter for the hemoglobin level. The variation in CFU-E inhibition for the same degree of anemia may be explained in part by other causes such as iron and folate deficiencies, osteitis fibrosa associated with hyperparathyroidism and aluminum toxicity.

In conclusion, the present study demonstrates the persistent presence of inhibitors of erythropoiesis mainly in patients receiving regular hemodialysis treatment. Serum ESF levels in both dialysis and predialysis patients were moderately high above the normal range, however, the titers were not sufficiently increased, and therefore inadequate ESF production was obviously an important factor of renal anemia. Similary, the increase of the inhibitor level may also be considered as playing an important role in renal anemia.

\section{References}

1) Becker, A.J., McCulloch, E.A., Siminovitch, L. \& Till, J.E. (1965) The effect of differing demands for blood cell production on DNA synthesis by hemopoietic colonyforming cells of mice. Blood, 26, 296-308.

2) Caro, J. \& Erslev, A.J. (1985) Uremic inhibitors of erythropoiesis. Semin. Nephrol., 5, 128-132.

3) Cotes, P.M. (1982) Immunoreactive erythropoietin in serum. Brit. J. Haematol., 50, $427-438$.

4) de Klerk, G., Hart, A.A.M., Kruiswijk, C. \& Goudsmit, R. (1978) Modified method of erythropoietin (ESF) bioassay in vitro using mouse fetal liver cells. II. Measurement of ESF in human serum. Blood, 52, 569-577.

5) de Klerk, G., Wilmink, J.M., Rosengarten, P.C.J., Vet, R.J.W.M. \& Goudsmit, R. (1982) Serum erythropoietin (ESF) titers in anemia of chronic renal failure. $J$. Lab. clin. Med., 100, 720-734.

6) Delwiche, F., Segal, G.M., Eshbach, J.W. \& Adamson, J.W. (1986) Hematopoietic inhibitors in chronic renal failure: Lack of in vitro specificity. Kidney Int., 29, 641648.

7) Dunn, C.D.R. \& Napier, J.A.F. (1978) Technical comments on the bioassay of erythropoietin. Exp. Hemat., 6, 577-584.

8) Dunn, C.D.R., Jarvis, J.H. \& Greenman, J.M. (1975) A quantitative bioassay for erythropoietin using mouse fetal liver cells. Exp. Hemat., 3, 65-78.

9) Fisher, J.W. (1980) Mechanism of the anemia of chronic renal failure. Nephron, 25, 106-111.

10) Fisher, J.W., Moriyama, Y., Lertora, J.J.L., Rege, A.B. \& Dukes, P.P. (1975) Mechanism of the anemia of renal disease. In : Erythropoiesis, edited by K. Nakao, J. W. Fisher \& F. Takaku, University of Tokyo Press, Tokyo, pp. 463-480.

11) Fukushima, Y. (1981) Erythropoietin (ESF) bioassay in vitro using fetal mouse liver cells (FMLC). Acta haematol. jap., 44, 1083-1088. (in Japanese with English abstract)

12) Krantz, S.B., Gallien-Lartigue, O. \& Goldwasser, E. (1963) The effect of erythropoietin upon heme synthesis by marrow cells in vitro. J. biol. Chem., 238, 40854090 . 
13) McGonigle, R.J.S., Husserl, F., Wallin, J.D. \& Fisher, J.W. (1984a) Hemodialysis and continuous ambulatory peritoneal dialysis effects on erythropoiesis in renal failure. Kidney Int., 25, 430-436.

14) McGonigle, R.J.S., Wallin, J.D., Shadduck, R.K. \& Fisher, J.W. (1984b) Erythropoietin deficiency and inhibition of erythropoiesis in renal failure. Kidney Int., 25, $437-444$.

15) McGonigle, R.J.S., Wallin, J.D., Husserl, F., Deftos, L.J., Rice, J.C., O'neill, W.J., Jr. \& Fisher, J.W. (1984c) Potential role of parathyroid hormone as an inhibitor of erythropoiesis in the anemia of renal failure. J. Lab. clin. Med., 104, 1016-1026.

16) McGonigle, R.J.S., Boineau, F.G., Beckman, B., Ohene-Frempong, K., Lewy, J.E., Shadduck, R.K. \& Fisher, J.W. (1985) Erythropoietin and inhibitors of in vitro erythropoiesis in the development of anemia in children with renal disease. $J$. Lab. clin. Med., 105, 449-458.

17) Meytes, D., Bogin, E., Ma, A., Dukes, P.P. \& Massry, S.G. (1981) Effect of parathyroid hormone on erythropoiesis. J. clin. Invest., 67, 1263-1269.

18) Müller-Wiefel, D.E. \& Schärer, K. (1983) Serum eythropoietin levels in children with chronic renal failure. Kidney Int., Suppl., S70-S76.

19) Ohno, Y., Rege, A.B., Fisher, J.W. \& Barona, J. (1978) Inhibitors of erythroid colony-forming cells (CFU-E and BFU-E) in sera of azotemic patients with anemia of renal disease. J. Lab. clin. Med., 92, 916-923.

20) Radtke, H.W., Claussner, A., Erbes, P.M., Scheuermann, E.H., Schoeppe, W. \& Koch, K.M. (1979) Serum erythropoietin concentration in chronic renal failure: Relationship to degree of anemia and excretory renal function. Blood, 54, 877-884.

21) Radtke, H.W., Rege, A.B., LaMarche, M.B., Bartos, D., Bartos, F., Campbell, R.A. \& Fisher, J.W. (1981) Identification of spermine as an inhibitor of erythropoiesis in patients with chronic renal failure. J.clin. Invest., 67, 1623-1629.

22) Shaw, A.B. (1967) Haemolysis in chronic renal failure. Brit. med. J., 2, 213-216.

23) Sherwood, J.B. \& Goldwasser, E. (1979) A radioimmunoassay for erythropoietin. Blood, 54, 885-893.

24) Teale, F.W.J. (1959) Cleavage of the haem-protein link by acid methylethylketone. Biochim. biophys. Acta, 35, 543.

25) Terasawa, T., Kimura, H., Maruyama, W. \& Kasai, S. (1979) An improved assay method for erythrocytic colony forming units in murine and human bone marrow. Acta haematol. jap., 42, 72-78.

26) Wallner, S.F. \& Vautrin, R.M. (1981) Evidence that inhibition of erythropoiesis is important in the anemia of chronic renal failure. J. Lab. clin. Med., 97, 170-178.

27) Wallner, S.F., Ward, H.P., Vautrin, R., Alfrey, A. \& Mishell, J. (1975) The anemia of chronic renal failure: In vitro response of bone marrow to erythropoietin. Proc. Soc. exp. Biol. Med., 149, 939-944.

28) Wallner, S.F., Vautrin, R.M., Kurnick, J.E. \& Ward, H.P. (1978) The effect of serum from patients with chronic renal failure on erythroid colony growth in vitro. $J$. Lab. clin. Med., 92, 370-375.

29) Zaroulis, C.G., Hoffman, B.J. \& Kourides, I.A. (1981) Serum concentrations of erythropoietin measured by radioimmunoassay in hematologic disorders and chronic renal failure. Amer. J. Hemat., 11, 85-92. 